\title{
VARIASI GENETIK LOCI STR CODIS (THO1,TPOX) MANUSIA GILIMANUK (PULAU BALI)
}

\section{LOCI STR CODIS (THO1,TPOX) GENETIC VARIATION ON GILIMANUK MAN (BALI ISLANDS)}

\author{
Toetik Koesbardiati ${ }^{1,4}$, Ahmad Yudianto ${ }^{2,4}$, Delta Bayu Murti \& Rusyad Adi Suriyanto ${ }^{3}$ \\ ${ }^{1}$ Departemen Antropologi, Fakultas IImu Sosial dan Ilmu Politik Universitas Airlangga \\ ${ }^{2}$ Program Magister Ilmu Forensik, Pascasarjana Universitas Airlangga \\ ${ }^{3}$ Laboratorium Bioantropologi dan Paleoantropologi, Fakultas Kedokteran \\ Universitas Gadjah Mada \\ ${ }^{4}$ Institute of Tropical Disease, Universitas Airlangga
}

\begin{abstract}
It is assumed that Mongoloid's migration came from western and northern part of Indonesia in various waves of migration. The migrant population then mixed with initial inhabitants, which are Australomelanesoid. The wave of migration moved further to the eastern Indonesia and mixed with migrant that entered from east (Papua). Some researches show that the concentration of mixture (hybridization) of migration was around Wallace's line. Gilimanuk is one of prehistoric site that yields Neolithic human remains. It is assumed that Gilimanuk can give worthy information about human variation at that time. The aim of the research is to describe the human genetic variation at site of Gilimanuk. The material is DNA (deoxyribonucleic acid) has been extracted from many piece of bone of Gilimanuk's human remains. We used STR (short tandem repeat) two loci (THO1 and TPOX) to gain human genetic variation. The result show all of sample yields band with different allele. This evidence confirms that they have a genetic affinity is not the same, or their genes from several population.
\end{abstract}

Keywords : Genetic Variation, Gilimanuk, Migration.

\begin{abstract}
ABSTRAK
Migrasi Mongoloid diduga berasal dari wilayah barat dan utara Indonesia yang datang dalam berbagai gelombang. Kelompok migran ini bercampur dengan penduduk setempat yang berafiliasi Australomelanesoid. Migrasi ini bergerak ke arah timur Indonesia dan bercampur dengan migran yang masuk dari wilayah timur (Papua). Beberapa penelitian menunjukkan bahwa konsentrasi percampuran (hibridisasi) ada di sekitar wilayah Garis Wallace sampai ke timur. Gilimanuk adalah salah satu situs prasejarah yang kaya akan temuan sisa-sisa manusia Neolitik. Diasumsikan bahwa Gilimanuk ini dapat memberi petunjuk variasi manusia di wilayah ini. Tujuan dari penelitian ini adalah untuk mendeskripsikan variasi genetik populasi Gilimanuk. Bahan penelitian adalah DNA (deoxyribonucleic acid) yang diambil dari sisa-sisa rangka individuindividu Gilimanuk. Metode yang digunakan adalah STR (short tandem repeat) dengan menggunakan dua loci (THO1 dan TPOX). Sampel menunjukkan band/pita dengan allele yang berbeda-beda. Bukti ini menegaskan bahwa mereka mempunyai afinitas atau kekerabatan genetik yang tidak sama, atau gen mereka berasal dari beberapa populasi.
\end{abstract}

Kata kunci : Variasi Genetik, Gilimanuk, Migrasi

Tanggal masuk : 16 September 2013

Tanggal diterima : 24 November 2013 


\section{PENDAHULUAN}

Rekonstruksi tentang penghunian wilayah-wilayah dunia adalah topik yang menarik dalam penelitian-penelitian bioantropologis dan bioarkeologis. Pengetahuan tentang pola-pola penghunian (migrasi dan kolonisasi) dapat diaplikasikan pada persoalanpersoalan masa kini, misalnya penelusuran evolusi, persebaran dan pola penyakit pada suatu populasi. Secara logis, migrasi manusia tidak hanya melibatkan biologi manusianya saja, melainkan juga kebudayaan, penyakit, domestifikasinya dan lain sebagainya yang terkait dengan kehidupannya (Cavalli-Sforza et al. 1988; Pusch et al. 2003; Donoghue et al. 2004; Mulligan 2006; Rollo et al. 2006; Baca \& Molak 2008; Rizzi et al. 2012). Oleh karena itu, aspek-aspek tersebut dapat digunakan untuk merekonstruksi kolonisasi dan penghunian populasi suatu wilayah, termasuk kawasan Indonesia di masa lampau sampai kini (Jacob 1967a, 1967b, 1974, 2006a, 2006b; Sukadana 1970, 1975, 1979, 1981, 1983, 1984; Glinka 1978, 1981, 1993; Suriyanto \& Koesbardiati 2006, 2010, 2012; Suriyanto et al. 2006, 2008; Glinka \& Koesbardiati 2007; Suriyanto 2007; Suriyanto et al. 2011; Koesbardiati et al. 2012; Koesbardiati et al. 2012; Suriyanto et al. 2012).

Koesbardiati \& Suriyanto (2007c) merekonstruksi pola migrasi Mongoloid dan Austromelanesoid di Indonesia berdasarkan antikuitas temuan arkeologisnya. Hasil penelitian ini menyimpulkan bahwa pola migrasi ini di Indonesia seperti sebuah pendulum yang bergerak dari barat ke timur wilayah negeri ini. Gerakan ayunannya dapat dianalogikan sebagai pola gerakan populasi pendatang (migrant population). Gerakan pendulum pertama mengayun ke arah timur, mendesak populasi sebelumnya (Australomelanesoid). Populasi asal semakin terdesak ke bagian timur Indonesia. Gerakan berikutnya adalah ayunan ke arah sebaliknya (barat) di mana ada migrasi balik dari populasi Australomelanesoid yang bergerak ke barat. Pola migrasi yang seperti pendulum ini diperkuat dengan penelitian tentang pola-pola modifikasi gigi-geliginya yang mengindikasikan adanya akulturasi atau percampuran dari pendatang (Koesbardiati \& Suriyanto 2007a, 2007b; Suriyanto \& Koesbardiati 2010; Suriyanto et al. 2011, Suriyanto et al. 2012). Beberapa pola modifikasi gigi adalah pencabutan, peruncingan, dan perataan. Pencabutan diduga adalah tradisi yang tertua karena pola ini tidak lagi banyak ditemukan sebagai suatu tradisi di Indonesia; sedangkan pola peruncingan adalah praktik modifikasi berikutnya. Praktik peruncingan gigi banyak ditemukan di Kepulauan Mentawai. Tradisi ini tetap dilakukan hingga sekarang. Pola modifikasi gigi yang terakhir adalah perataan. Perataan gigi, terutama perataan oklusalnya, tampaknya adalah pengaruh dari kelompok migran terakhir yang masuk. Hal ini dibuktikan dari masih banyaknya masyarakat yang masih mempraktikkan kebiasaan ini hingga sekarang. Kenyataan ini membawa petunjuk lain bahwa diduga ada akulturasi dan admixture yang memberikan kontribusi terhadap variasi genetik populasi Indonesia (Cox et al. 2010; Lansing et al. 2011).

Gilimanuk adalah salah satu situs arkeologis penting di Bali. Gilimanuk adalah situs kubur prasejarah pada masa Paleometalik yang mempunyai antikuitas sekitar 2000 tahun (Jacob 1967a, 1967b, 1974; Soejono 1977a, 1977b, 1979, 1995; Suprijo 1982, 1985; Supriyo 1991; Suriyanto 2012). Situs ini terletak di tepi pantai Gilimanuk dan sangat kaya dengan temuan sisa-sisa manusia, baik yang dikubur secara langsung maupun sekunder dalam tempayan. Terkait dengan pola migrasi dan kolonisasi pada masa prasejarah, sekitar Gilimanuk dapat merupakan persimpangan jalur migrasi populasi manusia kuno di antara Asia Tenggara Daratan dan pulau-pulau Pasifik (Melton et al. 1995; Kayser et al. 2001; Karafet et al. 2005; Jacob 2006a; Kayser et al. 2006; Suriyanto \& Koesbardiati 2006; Suriyanto et al. 2006; Suriyanto 2007; Kayser et al. 2008; Suriyanto et al. 2008; 
Mona et al. 2009; Karafet et al. 2010; Koesbardiati et al. 2012; Xu et al. 2012). Dalam pola ayunan pendulum seperti tersebut di atas, maka Gilimanuk terletak pada persimpangan wilayah ayunan ke timur dan ayunan kembali ke barat (Koesbardiati \& Suriyanto 2007; Suriyanto \& Koesbardiati 2012). Hal ini juga telah dibuktikan dari pola modifikasi giginya (Koesbardiati \& Suriyanto 2007a, 2007b; Suriyanto \& Koesbardiati 2010; Suriyanto et al. 2011, Suriyanto et al. 2012). Selain itu, diduga bahwa migrasi yang datang dari utara juga melalui wilayah sekitar Bali (Karafet et al. 2005; Karafet et al. 2010; Xu et al. 2012). Berdasarkan hal ini, diasumsikan bahwa variasi genetik di Gilimanuk akan tinggi.

Variasi genetik manusia ditentukan oleh variasi DNA (deoxyribonucleic acid)nya sebagai cetak biru yang memastikan karakteristik biologis seorang individu, di mana sangat dipengaruhi oleh urutan nukleotida yang disandi dalam struktur DNA-nya. Bila seorang individu mempunyai kekerabatan dekat dengan seorang individu lain atau kelompok individu di suatu wilayah dengan wilayah lain, bisa berupa suatu politipisme dan polimorfisme, maka tingkat persamaan informasi genetiknya akan tinggi pula. Variasi ini tentu saja sangat ditentukan oleh mutasi, rekombinasi dan migrasi gen dari satu lokasi ke lokasi lainnya. Penanda molekuler mengandalkan karakteristik DNA yang dapat diterapkan untuk mengidentifikasi variasi genom pada berbagai tingkat organisme. Pengembangan dan penerapannya untuk mendeteksi dan mengidentifikasi DNA polimorfisme merupakan bagian perkembangan paling signifikan dalam bidang genetika molekuler. Kemajuannya sampai ke masa kini dapat membantu analisis dalam penelitian evolusi dan migrasi manusia, bahkan spesimen-spesimen paleontologis, biologis-arkeologis, museum, medis dan forensik (Hermann \& Hummel 1994; Hummel \& Hermann 1994; Epplen 1994). Variasi dalam urutan DNA-nya menyumbangkan akurasi yang sangat tinggi karena tidak mampu diamati oleh penanda genetik lain, apalagi sebagian besar variasi di tingkat nukleotidanya acapkali tidak mampu diamati pada tingkat fenotipenya. Keunggulan penanda berbasis DNA ini dibandingkan penanda morfologis dan biokimiawi adalah bersifat diwariskan, relatif mudah diuji dan relatif tidak terpengaruh lingkungan. Keuntungannya adalah penelitian pada tingkat genotipenya dapat langsung diujikan daripada fenotipenya, bagian DNA yang berbeda itu dapat berevolusi dengan kecepatan yang berbeda sehingga bagian yang tepat dapat dipilih untuk penelitian dan analisis selanjutnya, dan dapat dipakai untuk memperjelas filogeni, paternitas dan genealogis atas spesimen atau temuan sisa-sisa biologis.

Penelitian ini bertujuan untuk mendeskripsikan variasi genetik populasi Gilimanuk masa prasejarah (Neolitik). Keuntungan yang signifikan dalam analisis molekuler sisa-sisa manusia prasejarah ini adalah bahwa data genealogis yang dihasilkan terkait langsung dengan kondisi saat itu. Dalam hal ini diharapkan bahwa penghunian di Gilimanuk dapat memberikan informasi variasi genetik manusia pada masa itu.

\section{BAHAN DAN METODE}

Penelitian ini bersifat pendahuluan, sebagai usaha untuk mendeteksi variasi genetik populasi bermaterikan ancient human bones. Oleh sebab itu, sementara ini kami hanya mencobakan terhadap dua loci untuk melihat kemungkinan penelitian lebih lanjut. Penelitian ini telah dilakukan di Laboratory of Human Genetic, Institute of Tropical Disease (ITD) Universitas Airlangga. Bahan penelitian adalah serpihan-serpihan rangka prasejarah individu-individu Gilimanuk, Bali.

Gilimanuk adalah situs kubur dan penghunian dari Zaman Paleometalik dengan antikuitas 1500-2000 tahun yang berada di pantai barat Bali, Kelurahan Gilimanuk, Kecamatan Melaya, Kabupaten Jembrana (Jacob 1967a, 1967b, 1974; Soejono 1995; Yuliati 1995, 1997). Hasil pertanggalan $C^{14}$ terhadap tulang-tulang manusianya telah ditemukan umur 1486-2466 tahun, sedangkan terhadap arangnya telah 
ditemukan umur 1805-1990 tahun (Azis et al. 1994). Letak situs berada pada bagian selatan dari Teluk Gilimanuk, dengan posisi koordinat $114^{\circ} 26^{\prime} 5^{\prime \prime}$ $114^{\circ} 29^{\prime} 10^{\prime \prime}$ Bujur Timur dan $8^{\circ} 9^{\prime} 3^{\prime \prime}$ $8^{\circ}$ 12' 59" Lintang Selatan, serta merupakan semenanjung kecil yang diapit Teluk Prapat Agung (Azis 1996). Situs ini juga berbentang alam satuan morfologis daratan pantai dengan stratigrafi satuan batu gamping, batupasir gampingan, endapan teras pantai I - II, dan pasir berlumpur yang meliputi luas $2 \mathrm{~km}^{2}$ (Yuliati 1995, 1997; Azis 1996). Sisa-sisa rangka manusianya ditemukan pada satuan endapan aluvial teras pantai yang tersebar di sebelah timur Teluk Gilimanuk, di mana mengikuti garis pantai secara lateral dan membentuk undak-undak secara vertikal (Azis 1995, 1996).
Penelitian dari tahun 1964 sampai kini telah dibuka 37 kotak ekskavasi, dan terkumpul 123 individu rangka manusia dari usia bayi sampai dewasa; serta dengan bekal kubur berupa beberapa gerabah, manik-manik, benda logam, cangkang kerang dan sisa binatang (Azis 1995; Yuliati 1995, 1997). Beberapa posisi penguburan telah ditemukan di sini, meliputi posisi terlentang tanpa wadah, posisi fleksi, dan penguburan dalam tempayan; di mana beberapa diantaranya terdiri dari dua tempayan yang disusun menangkup mulut dengan mulut (Soejono 1977a, 1977b, 1979). Sebagian kecil temuan telah didapatkan dari penguburan primer tanpa wadah, sedangkan yang lain dari penguburan sekunder dalam tempayan, serta gabungan dari penguburan primer dan sekunder (Azis 1995; Yuliati, 1995, 1997

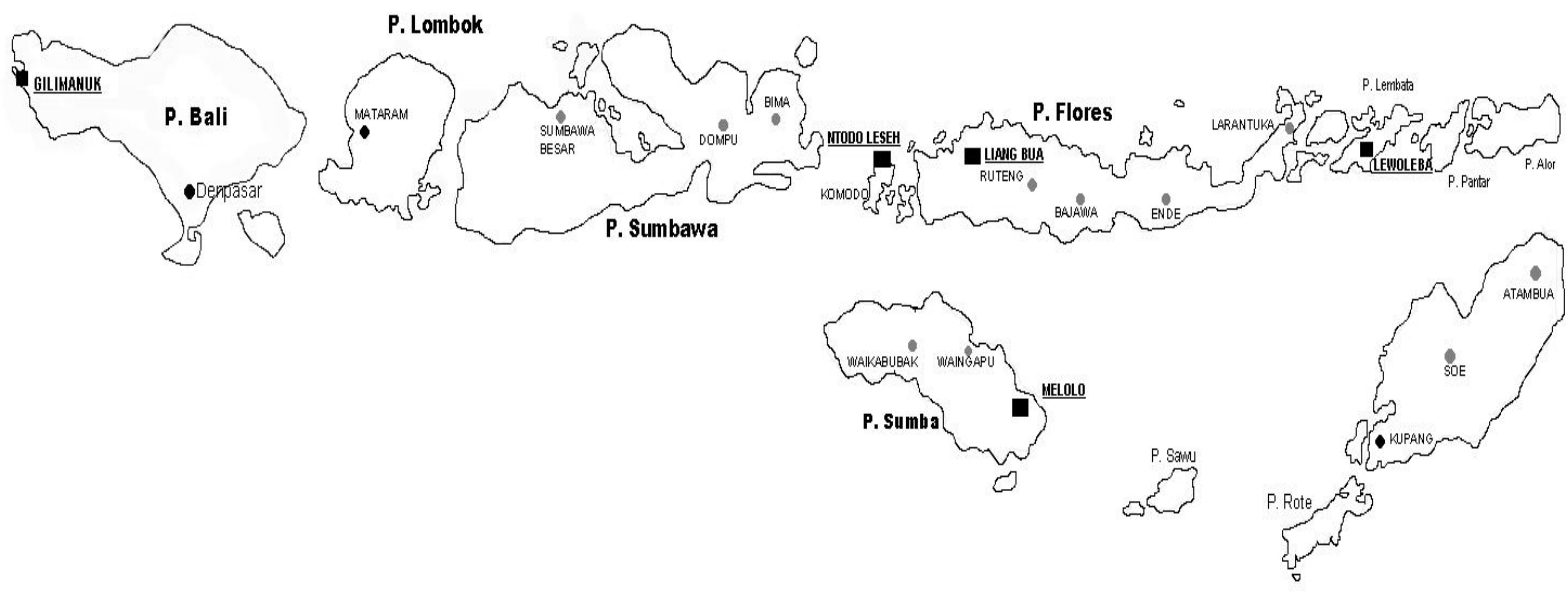

Gambar 1. Situs Gilimanuk dan situs-situs di bagian timurnya dalam deretan pulau-pulau busur luar Indonesia

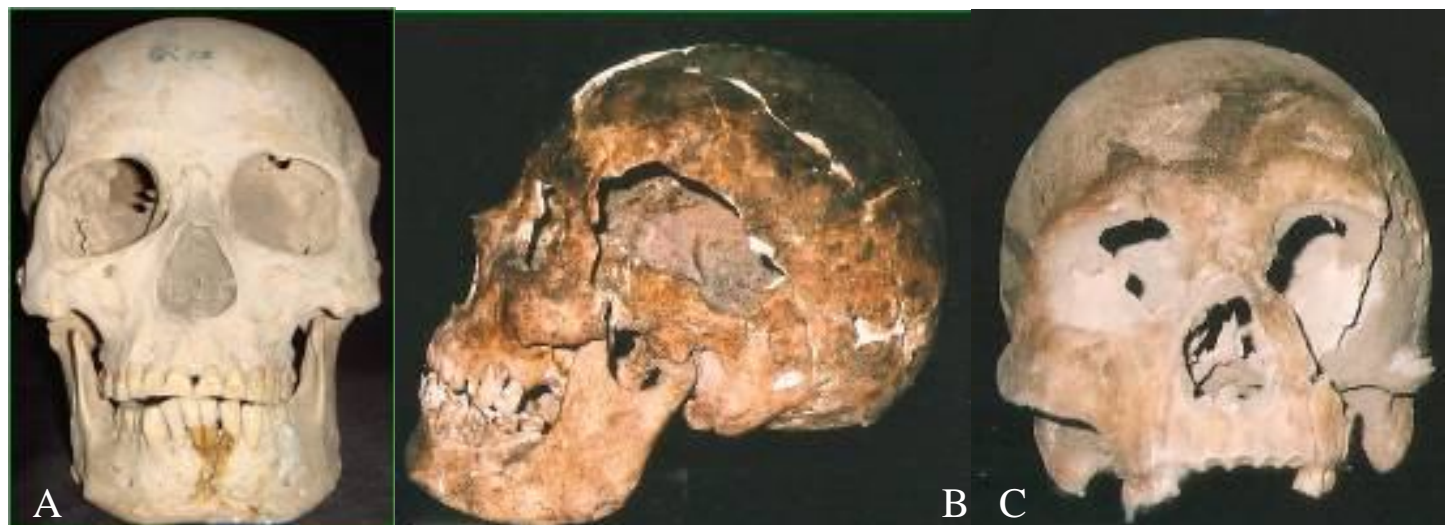

Gambar 2. Beberapa temuan sisa-sisa biologis manusia di situs Gilimanuk: A. R II, B. R VIIIA dan C. R CXIX 
Analisis DNA kuno (ancient DNA, aDNA) telah menjadi modus penelitian yang semakin populer dalam arkeologi dan evolusi manusia (Pusch et al. 2003; Keyser-Tracqui \& Ludes 2005; Mulligan 2006; Rizzi et al. 2012). Pendekatan ini kadangkala rumit oleh sifat terdegradasi dari asam nukleat kuno, kehadiran inhibitor enzim dalam ekstrak aDNA dan risiko kontaminasi selama penggalian atau manipulasi sampel. Meskipun kesulitan-kesulitan itu seringkali mengiringi, namun berbagai metode telah dikembangkan para ilmuwan beragam disiplin, khususnya minat genetika kuno, untuk mengoptimalkan pemulihan, kajian dan otentikasi aDNAnya. Seperti juga Witas (2001) dan Kemp et al. (2007) yang telah mengisyaratkan bahwa penelitian DNA terekstraksi dari spesimen arkeologis merupakan jalan baru bagi penelitian yang menarik yang dapat memberikan bukti yang unik untuk menangani pertanyaan-pertanyaan arkeologis. Di sini penelitian seperti ini dapat memberikan gambaran tentang studi kasus terkenal dalam sejarah penelitian arkeologis, yang menggunakan data genetika yang diambil dari spesimen arkeologis untuk membuat interpretasi tentang masa lalu. Yang juga menarik adalah variasi dalam urutan DNA, terutama manusia, karena kesimpulan yang dapat ditarik dari penelitian dengan metodologi itu dapat menjelaskan lebih luas bagaimana perjalanan evolusi, migrasi dan demografi kita. Selain itu penelitian ini juga dapat menjelaskan bagaimana DNA kuno berbeda dari DNA modern dan, dengan demikian, mengapa hanya beberapa penanda genomik tertentu biasanya ditargetkan dan mengapa protokol telah dikembangkan secara eksplisit untuk penelitian laboratoriumnya. Kami menghadirkan prosedur yang digunakan dalam laboratorium kami, seperti telah disarankan oleh Yang \& Watt (2005), untuk mengekstrak dan memperkuat segmen DNA informatif dari sampel manusia prasejarah atau protohistoris, serta mungkin dapat menyumbangkan tindakan pencegahan dan penerapan strategi untuk menghindari atau setidaknya mendeteksi jika terjadi kontaminasi pada koleksi bahan penelitian dari lapangan.

Penelitian ini telah menerapkan metode loci STR (short tandem repeat) polimorfik. Metode ini adalah suatu cara mengamati penanda-penanda genetik berbasis-PCR (the polymerase chain reaction) yang paling informatif terhadap upaya untuk individuasi material-material biologis (Edwards et al. 1991; Edwards et al. 1992; Budowle et al. 1995; Lins et al. 1998; Moretti et al. 1998; Bosch et al. 1999; Budowle et al. 1999; Biondo et al. 2001; Vecchio et al. 2004; Souiden et al. 2009). Budowle et al. (2001) menegaskan bahwa kita dapat memanfaatkan potensi penuh dari locus STR itu untuk memilih dan menetapkan lokus intinya untuk indeks DNA dan CODIS (yakni, Combined DNA Index System). Tiga belas loci CODIS STR resultan adalah CSF1PO, D3S1358, D5S818, D7S820, D8S1179, D13S317, D16S539, D18S51, D21S11, FGA, TH01, TPOX, dan VWA. Salah satu hasil utama dari upaya ini adalah memberikan landasan yang kokoh untuk memperkirakan frekuensi profilnya (Sun et al. 2003).

Betapa akuratnya metode itu, yang merupakan pengembangan dari ilmu dan teknologi genetika, seyogyanya penelitian ancient human DNA acapkali memperhatikan lingkungannya, karena lingkungan berandil memberikan analisis lebih luas dan dalam atas hasil penelitian laboratoriumnya yang sekedar berupa data penanda-penanda genetik itu. Oleh karena itu, sejak beberapa dekade yang lalu, Cavalli-Sforza et al. (1988) telah mengingatkan bahwa untuk merekonstruksinya hendaklah bersama data arkeologis dan linguistiknya. Secara garis besar, menurut mereka, bahwasannya jarak-jarak genetis di antara hampir semua kluster populasi dunia adalah proporsional terhadap waktu-waktu separasi arkeologisnya; sedangkan keluarga linguistiknya menunjukkan paralelisme yang cukup nyata di antara evolusi genetik dan linguistiknya. 


\section{PERLAKUAN SAMPLE}

Terlebih dulu masing-masing serpihan tulangnya dibuat bubukan dengan menggunakan mortar. Bubukan \pm 1 gram ini dimasukkan ke dalam eppendorf tube, dan didekalsifikasi dengan $40 \mathrm{ml}$ larutan EDTA $0,5 \mathrm{M} \mathrm{pH}$ 7,5; serta di-vortex secukupnya; berikut harus disonikasi selama 15 menit dan disentrifuse dengan kecepatan 2000 rpm selama 15 menit.

Pelet tulang yang sudah dicuci yang berasal dari \pm 1 gram bubukan tulang tersebut yang telah didekalsifikasi sebelumnya, dicampur dengan $1 \mathrm{ml}$ DNAZol, dengan cara di-vortex, dan kemudian diinkubasi selama 5 menit pada suhu kamar. Berikutnya dilakukan sentrifuse $10.000 \mathrm{rpm}$ selama 10 menit pada suhu $4^{\circ} \mathrm{C}$. Kemudian supernatant diambil dan dimasukkan ke dalam tabung baru. Di sini harus ditambahkan $0,5 \mathrm{ml}$ absolute ethanol (100\%), dan dibolak-balik, serta diinkubasi selama 1-3 menit. Sekali lagi dilakukan sentrifuse 4.000 rpm selama 1-2 menit pada suhu $4^{\circ} \mathrm{C}$, kemudian supernatant -nya dibuang secara hati-hati, agar DNA-nya tidak ikut terbuang.

Dilakukan pencucian pelet dengan ethanol $75 \% \quad 0,8-1 \mathrm{ml}$; dan setiap kali dicuci dengan ethanol $75 \%$, maka harus dibolak-balik selama 3-6 kali, yang selanjutnya di-sentrifuse $4000 \mathrm{rpm}$ selama 1-2 menit. Beriktutnya tabung ini diletakkan dengan posisi tegak selama 0,5-1 menit; dan di mana setelah itu ethanol $75 \%$ dibuang dengan cara pippeting atau decanting. Pencucian dengan ethanol $75 \%$ ini harus dilakukan dua kali. Pelet ini dikeringkan dengan cara membiarkan tabung terbuka selama 5-15 detik sesudah ethanol 75\% dibuang. Selanjutnya pada pelet ini ditambah dengan larutan $\mathrm{NaOH} 8 \mathrm{mM}$ sebanyak $0,2-0,3 \mathrm{ml}$ sebagai pelarut DNA-nya, dan di-vortex; kemudian dispindown dan disimpan pada suhu -20 $\stackrel{\circ}{ }$.

Primer: Terdiri dari Primer A (Primer 1/Up Steam) dan Primer B (Primer 2/Down steam). TH01:

Forward : 5'-CTGGGCACGTGAGGGCAGCGTCT-3' Reverse : 5'-TGCCGGAAGTCCATCCTCACAGTC-3' TPOX:

Forward : 5'-ACTGGCACAGAACAGGCATCTAGG-3' Reverse : 5'-GGAGGAACTGGGAACCACACAGGT-3'

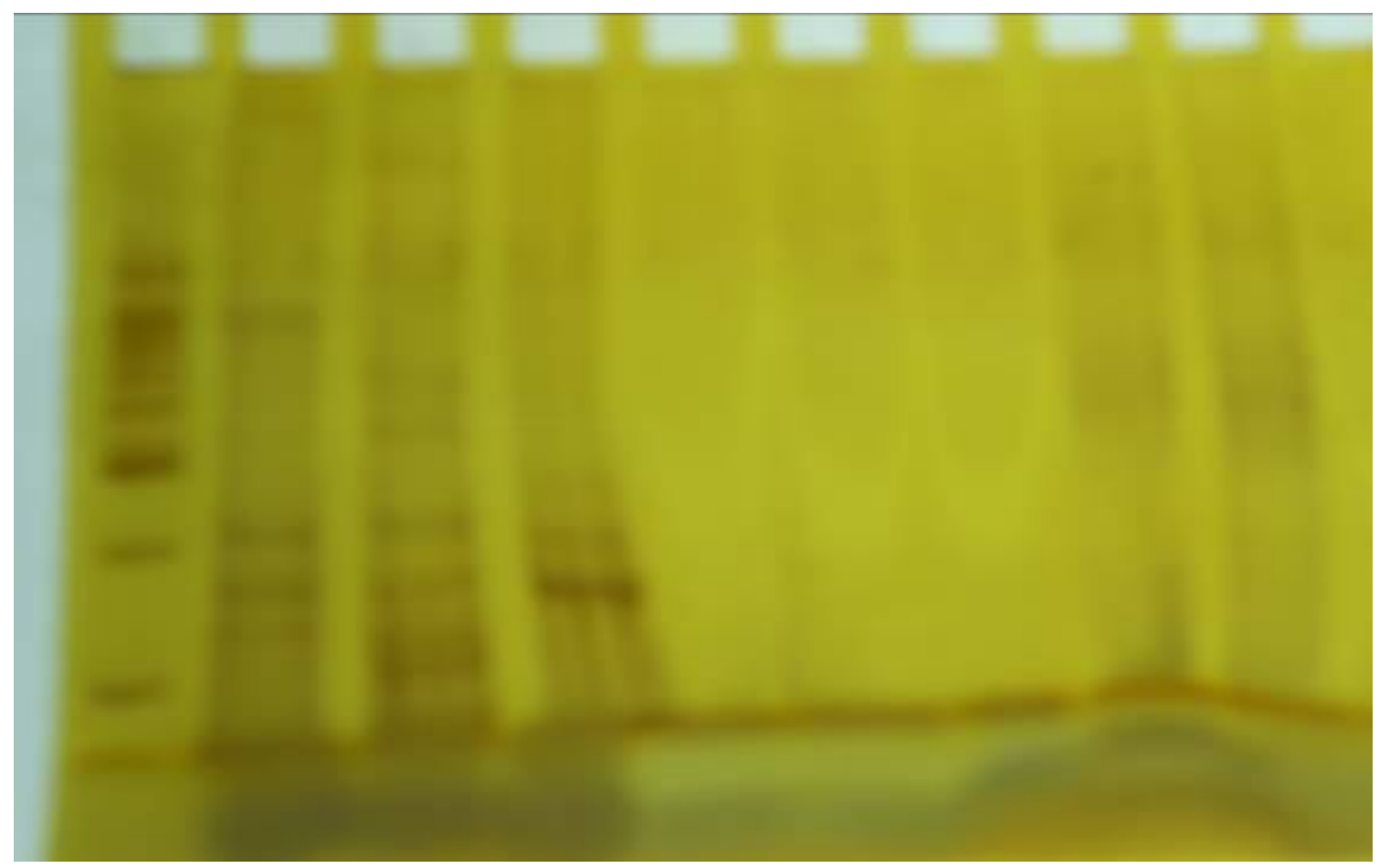

Gambar 3. Hasil band/pita sampel yang menunjukkan kekerapan yang tidak sama 


\section{HASIL DAN DISKUSI}

Deskripsi hasil elektroforesis (electrophoresis) menunjukkan sebagian besar sampel yang diperiksa genotipnya pada loci THO1 dan TPOX adalah homozigot. Semua sampel Gilimanuk masa prsejarah (sekitar Neolitik) ini menunjukkan band/pita dengan allele yang berbeda-beda. Bukti ini menegaskan bahwa mereka mempunyai afinitas atau kekerabatan genetik yang tidak sama, atau gen mereka berasal dari beberapa populasi. Sekalipun hanya dua lokus yang diperiksa, hasil ini dapat diarahkan pada pola admixture sebagai dampak dari migrasi. Dengan demikian, pemeriksaan dan analisis molekuler berikutnya akan memberi harapan lebih banyak mengenai pola migrasi yang tercermin dalam variasi genetiknya.

Secara geografis, Pulau Bali merupakan bagian dari gugusan pulaupulau yang menghubungkan pulau-pulau di bagian timur dan bagian barat Indonesia. Dari aspek Garis Wallace (Wallace's Line), Pulau Bali bisa jadi merupakan batu loncatan migrasi dari utara. Dengan demikian sangat dimungkinkan bahwa Pulau Bali dilalui jalur-jalur migrasi sehingga telah terjadi admixture pada populasi Pulau Bali masa itu. Sebagai konsekuensi dari hal ini adalah telah terjadi peristiwa heterogenitas, atau dengan kata lain, ada variasi genetik populasi Bali. Seberapa tinggi variasi tersebut belum dapat dipastikan di dalam penelitian ini karena penelitiannya masih bersifat pendahuluan dengan jumlah locus yang masih terbatas.

Berdasarkan penelitian $Y$ chromosome penduduk Pulau Bali saat ini, Karafet et al. (2005) menyimpulkan bahwa penduduk Pulau Bali ("asli”) saat ini adalah hasil percampuran dari berbagai elemen. Pengaruh paling awal terhadap paternal gene pool di Bali saat itu berasal dari pre-Neolithic huntergatherer. Gelombang migrasi masa Neolitik ini bersifat jamak, bukan single migration, dan melalui beberapa rute. Pengaruh berikutnya adalah ekspansi Mongoloid (Austronesian farmer). Pengaruh yang terakhir berasal dari masa sejarah yaitu ketika kontak antara India mulai intensif. Hal ini dapat diketahui dari banyaknya serapan kebudayaan India termasuk Hindu yang bertahan hingga sekarang. Kontak dagang, persebaran agama dan kolonisasi Belanda juga berperan penting pada paternal gene pool di Bali. Hasil penelitian Karafet et al. (2005) ini memperkuat penelitian sebelumnya oleh Handoko et al. (2001) berdasar variasi mtDNA pada populasi Indonesia. Hasil penelitian itu menunjukkan bahwa variasi genetik populasi Indonesia berasal dari berbagai populasi sekitar masa lalu itu. Shepard et al. (2005) telah meneliti 15 loci STR atas 338 unrelated individuals dari penduduk Ami dan Atayal di Taiwan, Bali dan Jawa di Indonesia, dan Samoa. Penelitian mereka menegaskan bahwa selalu ada derajat variasi genetis di antara sumber gen utama Australomelanesoid dan Mongoloid di antara mereka, yang berarti selalu ada saling pengaruh atau cetak biru di antara mereka, yang dipengaruhi oleh berbagai intensitas proses migrasi dan kontak kultural. Bahkan hasil penelitian mtDNA berikutnya oleh Lie et al. (2007) makin memperkokoh temuan-temuan tersebut.

$\mathrm{Xu}$ et al. (2012) telah melakukan penelitian molekuler terkait dengan dugaan adanya korespondensi antara populasi Asia dan Papua yang dipengaruhi oleh ekspansi Austronesia ke wilayah Asia Timur. Hasil penelitian ini menunjukkan bahwa co-existence di antara Asia dan Papua terjadi di sekitar Indonesia bagian timur. Melton et al. (1995), Lum et al. (1998) dan Mona et al. (2009) telah mengisyaratkan peristiwa ini berdasarkan hasil penelitian terhadap hubungan-hubungan mtDNA di antara populasi Asia dan Pasifik. Bahkan Mona et al. (2009) menambahkan argumentasinya dengan yakin tentang sejarah percampuran genetik populasipopulasi Indonesia Timur di kepulauan kawasan Nusa Tenggara Timur dan Timor Leste; dan ini makin memberi terang bukti penelitian ini. Mereka telah menegaskan bahwa kawasan ini merupakan genetic melting pot antara populasi Austronesia (Mongoloid) dan Melanesia (Australomelanesoid). 
Kawasan ini sebelumnya telah dihuni populasi non-Austronesia, yang kemudian lambat-laun bercampur dengan populasi Austronesia. Dalam hal apapun, komponen-komponen genetik mereka telah muncul dalam semua kelompok populasi kawasan ini tanpa memandang bahasa mereka saat ini. Di sini mereka telah menunjukkan sejarah panjang percampuran genetik di Nusa Tenggara Timur dan Timor Leste beserta kawasan sekitarnya. Hal ini memberi peluang bahwa pengaruh tersebut juga ada hingga di Bali, mengingat bahwa Pulau Bali adalah salah satu mata rantai jalur migrasi dalam gugusan pulau busur luar Indonesia menuju wilayah timur Indonesia dan Pasifik (Jacob 1967a, 1967b, 1994, 2006a; Sukadana 1970, 1979, 1981, 1984; Glinka 1981, 1983; Suprijo 1982, 1985; Merriwether 1999; Kayser et al. 2001; Underhill et al. 2001; Bird et al. 2004; Cox 2005; Kayser et al. 2006; Suriyanto et al. 2006; Hill et al. 2007; Suriyanto 2007; Kayser et al. 2008; Kayser et al. 2008; Cox et al. 2010; McEvoy et al. 2010; Koesbardiati et al. 2012; Suriyanto \& Koesbardiati 2012, Suriyanto et al. 2012). Bahkan Jinam et al. (2012) memperkirakaan antikuitas migrasinya, berdasarkan model migrasi genetika populasi dari Asia ke gugusan pulau busur luar Indonesia menuju wilayah-wilayah timurnya itu, telah berlangsung sekitar 30.000-10.000 tahun sebelum Tarikh Masehi.

Lansing et al. (2011) telah menunjukkan hubungan kebudayaan dan genetika dalam peristiwa ekspansi Austronesia ke Asia Tenggara Kepulauan. Mereka meneguhkan bahwa distribusi genetik NRY (kromosom Y) dan mtDNA (mitochondrial DNA) menunjukkan adanya korelasi, bahwa pengaruh migrasi dan perkawinan dapat menghasilkan perubahan bahasa yang bersifat seismik dan pergeseran genetik. Mereka menunjukkan tengaranya bahwa diskontinuitas bahasa dan genetik ini telah terjadi di sekitar kawasan Bali sampai Flores. Mereka sebenarnya juga berkolaborasi atas penelitian sebelumnya, baik di dalam Cox et al. (2007) maupun Kayser et al. (2008), yang secara garis besar menunjukkan bahwa sebagian besar mtDNA di dalam populasi Polinesia berasal dari Asia; dan sebagian besar kromosom $Y$ yang mencapai $94 \%$ di dalam populasi Melanesia berasal dari Polinesia, sedangkan mtDNA-nya berasal dari Asia Timur; dan $66 \%$ kromosom $Y$ di dalam populasi Polinesia berasal dari Melanesia. Di sini jadi makin menarik dengan memperhatikan apa yang telah diungkapkan oleh Laland et al. (2010), bahwa perkembangan manusia telah dibentuk oleh interaksi gen dan kebudayaan. Oleh karena itu, kebudayaan berperan dalam proses itu karena kebudayaan memungkinkan mereka beradaptasi relatif tepat terhadap perubahan-perubahan lingkungan dengan cara imitasi, yakni meniru kebudayaan populasi lain yang sudah lebih dulu mempratekkan dan berhasil mengatasi tantangan lingkungannya. Kebudayaan ini dalam tahap tertentu dapat memberikan pengaruh terhadap laju frekuensi suatu allele dalam menaggapi seleksi alam atas lingkungannya tersebut. Mona et al. (2007) telah membuktikan asumsi itu sebelumnya atas keanekaragaman variasi genetik penduduk kawasan Kepala Burung, Papua Barat, bahwa sebenarnya sejarah kromosom Y-nya merupakan sejarah lokal dengan beberapa kontribusi eksternal (Austronesia) yang telah dipengaruhi oleh berbagai hambatan karena proses migrasi dan kultural. Pengaruh tersebut dapat mempercepat atau memperlambat suatu frekuensi allele tertentu. Perkembangan lebih jauh, menurut Henrich \& Henrich (2011), populasi tersebut akan cenderung berbagi gen yang sama kepada para anggota populasi dalam satu genealogisnya. Wajarlah jika populasi Bali pada sekitar masa Neolitik mengalami diskontinuitas genetik, yang berarti ada variasi genetik di dalamnya. Untuk memperlihatkan kesinambungan ke populasi Bali masa kini, kami menghadirkan bukti dari penelitian Junitha \& Sudirga (2007), di mana mereka telah melakukan penelitian variasi DNA mikrosatelit kromosom $\mathrm{Y}$ pada populasi Bali Mula, Terunyan, guna 
mencari jejak asal-usul mereka. Perlu diketahui, masih kuatnya anggapan sampai sejauh ini, bahwa Orang Terunyan masih dianggap sebagai "Orang Bali Asli" (Danandjaja 1985, 1989; Wikarman 1994). Mereka menyimpulkan penelitiannya:

"Hasil penelitian ini menunjukkan bahwa masyarakat Terunyan tidak berasal dari satu leluhur tetapi diturunkan oleh banyak leluhur atau banyak sumber gen" (Junitha \& Sudirga 2007, 36).

\section{PENUTUP}

Secara geografis, Pulau Bali terletak pada posisi penting yang menghubungkan wilayah timur dan wilayah barat Indonesia; bahkan juga menghubungkan wilayah selatan dan utara Indonesia. Dengan demikian, sangat dimungkinkan bahwa Pulau Bali adalah lokasi persimpangan jalur migrasi di masa lalu. Saat ini Pulau Bali lebih memberi peluang besar terjadinya percampuran antar-populasi atau budaya terkait dengan infrastruktur pariwisata maupun daya tarik lainnya. Penelitian-penelitian bioarkeologis menunjukkan adanya kontinuitas modifikasi gigi pada masyarakat Bali yang masih terpelihara hingga sekarang.
Hal ini mengindikasikan bahwa ada pengaruh akulturasi budaya/tradisi yang berawal pada masa lalu. Dimungkinkan pula terjadi percampuran antar penduduk melalui hibridisasi dari penduduk asal dengan pendatang (migrant population) yang telah terjadi secara intensif sehingga mempengaruhi varasi genetik populasi Bali. Dari sudut pandang tersebut maka dapat dipastikan bahwa Pulau Bali sudah bervariasi secara genetik sejak dulu.

Dari berbagai hasil penelitian berbasis genetik menunjukkan bahwa pengaruh variasi genetik populasi Bali telah berawal sejak masa Neolitik. Sampel penelitian ini, dan dituliskan sebagai hasil prelimanary study, berasal dari masa Neolitik hingga awal Paleometalik sehingga hasil penelitiannya dapat langsung mewakili variasi genetik masa Neolitik dan Paleometalik itu. Prelimanary study ini sekaligus sebagai referensi untuk melakukan penelitian lanjutan yang tentu akan lebih detail dan terarah dengan teknik-teknik yang mendukung dan sesuai. 


\section{DAFTAR PUSTAKA}

Azis, F.A. 1995. "Situs Gilimanuk (Bali) sebagai pilihan lokasi penguburan pada Awal Masehi" dalam Berkala. Arkeologi, Edisi khusus. Yogyakarta: Balai Arkeologi Yogyakarta. HIm. 43-46.

1996. "Morfokronologi situs Gilimanuk dan sekitarnya" dalam S. Atmosoediro (ed.) Jejak-jejak Budaya II. Yogyakarta: Asosiasi Prehistorisi Indonesia. HIm. 105134.

Azis, F.A., W. Faizal \& F. Lahagu. 1994. "Pertanggalan radiokarbon rangka manusia situs Gilimanuk, Bali". Proceeding Evaluasi Hasil Penelitian Arkeologi. Jakarta: Pusat Penelitian Arkeologi Nasional.

Baca, M. \& Molak, M. 2008. "Research on ancient DNA in the Near East" dalam Bioarchaeology of the Near East 2. HIm. 39-61.

Biondo, R., A. Spinella, P. Montagna, P.S. Walsh, C. Holt, \& B. Budowle. 2001. "Regional Italian allele frequencies at nine short tandem repeat loci" dalam Forensic Science International 115. HIm. 95-98.

Bird, M.I., G. Hope \& D. Taylor. 2004. "Populating PEP II: the dispersal of humans and agriculture through Austral-Asia and Oceania" dalam Quaternary International 118 \&119. HIm. 145-163.

Bosch, E., F. Calafell, F.R. Santos, A. Pérez-Lezaun, D. Comas, N. Benchemsi, C. TylerSmith \& J. Bertranpetit. 1999. "Variation in Short Tandem Repeats is deeply structured by genetic background on the human $\mathrm{Y}$ chromosome" dalam The American Journal of Human Genetics 65. HIm. 1623-1638.

Budowle, B., F.S. Baechtel, C.T. Comey, A.M. Giusti \& L. Klevan. 1995. "Simple protocols for typing forensic biological evidence: chemiluminescent detection for human DNA quantitation and RFLP analyses and manual typing of PCR amplified polymorphisms" dalam Electrophoresis 16. HIm. 1559-1567.

Budowle, B., T.R. Moretti, A.L. Baumstark, D.A. Defenbaugh \& K.M. Keys. 1999. "Population data on the thirteen CODIS core short tandem repeat loci in African Americans, U.S. Caucasians, Hispanics, Bahamians, Jamaicans, and Trinidadians" dalam Journal of Forensic Sciences 44. HIm. 1277-1286.

Budowle, B., B. Shea, S. Niezgoda, \& R. Chakraborty. 2001. "CODIS STR loci data from 41 sample populations" dalam Journal of Forensic Sciences 46. HIm. 453-489.

Cavalli-Sforza, L.L., A. Piazza, P. Menozzi \& J. Mountain. 1988. "Reconstruction of human evolution: Bringing together genetic, archaeological, and linguistic data" dalam Proceeding of the National Academy of Sciences USA 85. HIm. 6002-6006.

Cox, M.P. 2005. "Indonesian mitochondrial DNA and its opposition to Pleistocene era origin of Proto-Polynesians in Island Southeast Asia" dalam Human Biology 77. HIm. 179-188.

Cox, M.P., Karafet, T.M., Lansing, J.S., Sudoyo, H. \& Hammer, M.F. 2010. "Autosomal and $X$ linked SNPs reveal a sharp transition from Asian to Melanesian ancestry in eastern Indonesia and a female-bias in admixture rates". Proceedings of the Royal Society of London Series B 277: 1589 - 1596. 
Cox, M.P., A.J. Redd, T.M. Karafet, C.A. Ponder, J.S. Lansing, H. Sudoyo \& M.F. Hammer. 2007. "A Polynesian motif on the $Y$ chromosome: population structure in remote Oceania" dalam Human Biology 79. HIm. 525-535.

Danandjaja, J. 1985. Upacara-upacara Lingkaran Hidup di Trunyan, Bali. Jakarta: Balai Pustaka.

1989. Kebudayaan Petani Desa Trunyan di Bali. Jakarta: UI Press.

Donoghue, H.D., M. Spigelman, C.L. Greenblatt, G. Lev-Maor, G.K. Bar-Gal, C. Matheson, K. Vernon, A.G. Nerlich \& A.R. Zink. 2004. "Tuberculosis: from prehistory to Robert Koch, as revealed by ancient DNA" dalam The Lancet 4. HIm. 584-592.

Edwards, A., A. Civitello, H.A. Hammond \& C.T. Caskey. 1991. "DNA typing and genetic mapping with trimeric and tetrameric tandem repeats" dalam American Journal of Human Genetics 49. HIm. 746-756.

Edwards, A., H.A. Hammond, L. Jin., C.T. Caskey \& R. Chakraborty. 1992. "Genetic variation at five trimeric and tetrameric repeat loci in four human population groups" dalam Genomics 12. HIm. 241-253.

Epplen, J.T. 1994. "Simple repeat loci as tools for genetic identification", dalam B. Hermann \& S. Hummel (eds.) Ancient DNA: Recovery and Analysis of Genetic Material from Paleontological, Archaeological, Museum, Medical, Forensic Specimens. New York: Springer-Verlag New York Inc. Hal. 13 - 30.

Glinka, J. 1978. Gestalt und Herkunft: Beitrag zur Anthropologischen Gliederung Indonesiens. St. Augustin: Verlag des Anthropos-Instituts.

Glinka, J. 1981. "Racial history of Indonesia" dalam I. Schwidetzky (ed.) Rassengeschichte der Menschheit. München: R. Oldenbourg Verlag. HIm. 79-133.

Glinka, J. 1993. "Reconstruction the past from present". Paper for International Conference on Human Paleocology: Ecological Context of the Evolution of Man. Jakarta: Lembaga IImu Pengetahuan Indonesia.

Glinka, J. \& Koesbardiati, T. 2007. "Morfotipe wajah dan kepala di Indonesia: suatu usaha identifikasi variasi populasi" dalam Jurnal Anatomi Indonesia 2. HIm. 41-46.

Handoko, H.Y., J.K. Lum, Gustiani, Rismala, H.H. Kartapradja, A.S. Sofro \& S. Marzuki. 2001. "Length variants in the COll-tRNA ${ }^{\text {lyss }}$ intergenic region of mitochondrial DNA in Indonesian populations" dalam Human Biology 73. HIm. 205-223.

Hill, C., P. Soares, M. Mormina, V. Macaulay, D. Clarke, P.B. Blumbach, M. VizueteForster, P. Forster, D. Bulbeck, S. Oppenheimer \& M. Richards. 2007. "A mitochondrial stratigraphy for Island Southeast Asia" dalam The American Journal of Human Genetics 80. HIm. 29-43.

Henrich, J. \& Henrich, N. 2006. "Culture, evolution and the puzzle of human cooperation" dalam Cognitive Systems Research 7. HIm. 220-245.

Hermann, B. \& S. Hummel. 1994. "Introduction” dalam B. Hermann \& S. Hummel (eds.) Ancient DNA: Recovery and Analysis of Genetic Material from Paleontological, 
Archaeological, Museum, Medical, Forensic Specimens. New York: Springer-Verlag New York Inc. HIm. 1-12.

Hummel, S. \& B. Hermann. 1994. "General aspects of sample preparation" dalam B. Hermann \& S. Hummel (eds.) Ancient DNA: Recovery and Analysis of Genetic Material from Paleontological, Archaeological, Museum, Medical, Forensic Specimens. New York: Springer-Verlag New York Inc. HIm. 59-68.

Jacob, T. 1967a. "Racial identification of the Bronze Age human dentitions from Bali, Indonesia" dalam Journal of Dental Research 5. HIm. 903-910.

1967b. Some Problems Pertaining to the Racial History of the Indonesian Region. Utrecht: Drukkerij Neerlandia.

1974. "Studies on human variation in Indonesia" dalam Journal of the National Medical Association 66. HIm. 389-399.

2006a. Manusia Makhluk Gelisah: Melalui Lensa Bioantropologi. Surakarta: Muhammadiyah University Press.

2006b. "The problem of Austronesia origin" dalam T. Simanjuntak, I.H.E. Pojoh \& M. Hisyam (eds.) Austronesian Diaspora and the Ethnogeneses of People in Indonesian Archipelago. Jakarta: LIPI Press. HIm. 7-13.

Jinam, T.A., L.C. Hong, M.E. Phipps, M. Stoneking, M. Ameen, J. Edo, HUGO PanAsian SNP Consortium \& N. Saitou. 2012. "Evolutionary history of continental southeast Asians: "early train" hypothesis based on genetic analysis of mitochondrial and autosomal DNA data" dalam Molecular Biology and Evolution 29. HIm. 3513-3527.

Junitha, I.K. \& S.K. Sudirga. 2007. "Variasi DNA mikrosatelit kromosom Y pada masyarakat Bali Mula Terunyan" dalam HAYATI Journal of Biosciences 2. HIm. 5964.

Karafet, T.M., J.S. Lansing, A.J. Redd, J.C. Watkins, S.P.K. Surata, W.A. Arthawiguna, L. Mayer, M.J. Bamshad, B. Lynn \& M.F. Hammer. 2005. "Balinese Y-chromosome perspective on the peopling of Indonesia: genetic contributions from Pre-Neolithic hunter-gatherers, Austronesian farmers, and Indian traders" dalam Human Biology 77. HIm. 93-114.

Karafet, T.M., B. Hallmark, M.P. Cox, H. Sudoyo, S. Downey, J.S. Lansing \& M.F. Hamme. 2010. "Major east-west division underlies $Y$ chromosome stratification across Indonesia" dalam Molecular Biology and Evolution 27. HIm. 1833-1844.

Kayser, M., S. Brauer, G. Weiss, W. Schiefenhövel, P.A. Underhill \& M. Stoneking. 2001. "Independent histories of human Y chromosomes from Melanesia and Australia" dalam The American Journal of Human Genetics 68. HIm. 173-190.

Kayser, M., S. Brauer, R. Cordaux, A. Casto, O. Lao, L.A. Zhivotovsky, C. Moyse-Faurie, R.B Rutledge, W. Wulf Schiefenhoevel, D. Gil, A.A. Lin, P.A. Underhill, P.J. Oefner, R.J. Trent \& M. Stoneking. 2006. "Melanesian and Asian origins of Polynesians: mtDNA and Y chromosome gradients across the Pacific" dalam Molecular Biology and Evolution 23. HIm. 2234-2244. 
Kayser, M., Y. Choi, M. van Oven, S. Mona, S. Brauer, R.J. Trent, D. Suarkia, W. Schiefenhovel \& M. Stoneking. 2008. "The impact of the Austronesian expansion: evidence from mtDNA and $\mathrm{Y}$ chromosome diversity in the Admiralty Islands of Melanesia" dalam Molecular Biology and Evolution 25. HIm. 1362-1374.

Kayser, M., Lao, O., Saar, K., Brauer, S., Wang, X., Nürnberg, P., Trent, R.J. \& Stoneking, M. 2008. "Genome-wide analysis indicates more Asian than Melanesian ancestry of Polynesians". The American Journal of Human Genetics 82: 194 - 198.

Kemp, B.M., C. Monroe \& D.G. Smith. 2007. "Extraction and analysis of DNA from archaeological specimens" dalam American Chemical Society Symposium Series 968. HIm. 78-98.

Keyser-Tracqui, C. \& B. Ludes. 2005. "Methods for the study of ancient DNA" dalam Methods in Molecular Biology 297. HIm. 253-264.

Koesbardiati, T. \& R.A. Suriyanto. 2007a. "Menelusuri jejak populasi morfologi pangur gigi geligi: kajian pendahuluan atas sampel gigi geligi dari beberapa situs purbakala di Jawa, Bali dan Nusa Tenggara Timur" dalam Humaniora 19. HIm. 33-42.

2007b. "Dental modification in Flores: a biocultural perspective" dalam E. Indriati (ed.) Recent Advances on Southeast Asian Paleoanthrpology and Archeology. Yogyakarta: Laboratory of Bioanthropology and Paleoanthropology Faculty of Medicine Gadjah Mada University. HIm. 259-268.

2007c. "Australomelanesoid in Indonesia: a swinginglike movement" dalam Jurnal Anatomi Indonesia 2. HIm. 23-28.

Koesbardiati, T., D.B. Murti \& R.A. Suriyanto.. 2012. "Leprosy on Plawangan skull: evidences for mongoloidization?" dalam T. Koesbardiati (ed.) Proceeding Book The International Seminar Celebrating the $80^{\text {th }}$ Birthday of Professor Dr. Habil Josef Glinka, SVD. Surabaya: Departement of Anthropology Faculty of Social and Political Sciences Airlangga University. HIM. 135-141.

Koesbardiati, T., R.A. Suriyanto \& D.B. Murti. 2012 "Bali: Cross road migrasi pada masa prasejarah" dalam N.M. Karmaya, I.W. Sugiratama, I.G.A. Widianti, I.A.I. Wahyuniari, I.N.G. Wardana, I.G.K.N. Arijana, I.G.N.S. Wiryawan, I.W. Suarya, I.G.N. Mayun, Muliani, Yuliana, N.M. Linawati, I.G.A.D. Ratnayanti, I.W. Suwitra, I.W. Semadha, I.N. Sueta \& I.G.N.P. Sana (eds.) Anatomy for Better Quality of Life, Proceeding Book Pertemuan IImiah Nasional Perhimpunan Ahli Anatomi Indonesia. Denpasar: Udayana University Press. HIM. 429-440.

Lansing, J.S., M.P. Cox, , T.A. de Vet, S.S. Downey, B. Hallmark \& H. Sudoyo. 2011. "An ongoing Austronesian expansion in Island Southest Asia" dalam Journal of Anthropological Archaeology 30. HIm. 262-272.

Li, H., X. Cai, E.R. Winograd-Cort, B. Wen, X. Cheng, Z. Qin, W. Liu, Y.Liu, S. Pan, J. Qian, C.-C. Tan \& J. Li. 2007. "Mitochondrial DNA diversity and population differentiation in Southern East Asia" dalam American Journal of Physical Anthropology 134. HIm. 481-488.

Lins, A.M., K.A. Micka, C.J.Sprecher, J.A.Taylor, J.W. Bacher, D.R. Rabbach, R.A. Bever, S.D. Creacy \& J.W. Schumm. 1998. "Development and population study of an eightlocus short tandem repeat (STR) multiplex system" dalam Journal of Forensic Sciences 43. HIm. 1168-1180. 
Lum, J.K., R.L. Cann, J.J. Martinson \& L.B. Jorde. 1998. "Mitochondrial and nuclear genetic relationships among Pacific Island and Asian populations" dalam The American Journal of Human Genetics 63. HIm. 613-624.

McEvoy, B.P., J.M. Lind, E.T. Wang, R.K. Moyzis, P.M. Visscher, S.M. van Holst Pellekaan \& A.N. Wilton. 2010. "Whole-genome genetic diversity in a sample of Australians with deep aboriginal ancestry" dalam The American Journal of Human Genetics 87. HIm. 297-305.

Melton, T., R. Peterson, A.J. Redd, N. Saha, A.S.M. Sofro, J. Martinson \& M. Stoneking. 1995. "Polynesian genetic affinities with Southeast Asian populations as identified by mtDNA analysis" dalam The American Journal of Human Genetics 57. HIm. 403-414.

Merriwether, D.A., J.S. Friedlaender, J. Mediavilla, C. Mgone, F. Gentz \& R.E. Ferrell. 1999. "Mitochondrial DNA variation is an indicator of Austronesian influence in Island Melanesia" dalam American Journal of Physical Anthropology 110. HIm. 243270.

Mona, S., K.E. Grunz, S. Brauer, B. Pakendorf, Loredana Castrí, H. Sudoyo, S. Marzuki, R.H. Barnes, J. Schmidtke, M. Stoneking \& M. Kayser. 2009. "Genetic admixture history of eastern Indonesia as revealed by Y-chromosome and mitochondrial DNA analysis" dalam Molecular Biology and Evolution 26. HIm. 1865-1877.

Mona, S., M. Tommaseo-Ponzetta, S. Brauer, H. Sudoyo, S. Marzuki \& M. Kayser. 2007. "Patterns of Y-chromosome diversity intersect with the Trans-New Guinea hypothesis" dalam Molecular Biology and Evolution 24. HIm. 2546-2555.

Moretti, T.R., B.W. Koons \& B. Budowle. 1998. "Enhancement of PCR amplification yield and specificity using AmpliTaq Gold ${ }^{\text {TM }}$ DNA polymerase" dalam BioTechniques 25. HIm. 716-722.

Mulligan, C.J. 2006. "Anthropological applications of ancient DNA: Problems and prospects" dalam American Antiquity 71. HIm. 365-380.

Pusch, C.M., M. Broghammer \& N. Blin. 2003. "Molecular phylogenetics employing modern and ancient DNA" dalam Journal of Applied Genetics 44. HIm. 269-290.

Rizzi, E., M. Lari, E. Gigli, G. De Bellis \& D. Caramelli. 2012. "Ancient DNA studies: new perspectives on old samples" dalam Genetics Selection Evolution 44. HIm. 21.

Rollo, F., L. Ermini, S. Luciani, I. Marota \& C. Olivieri. 2006. "The study of bacterial DNA in ancient human mummies" dalam Journal of Anthropological Sciences 84 . HIm. 53-64.

Shepard, E.M., R.A. Chow, E. Suafo'a, D. Addison, A.M. Perez-Miranda, R.L. GarciaBertrand \& R.J. Herrera. 2005. "Autosomal STR Variation in Five Austronesian Populations" dalam Human Biology 6. HIm. 825-851.

Soejono, R.P. 1977a. Sarkofagus Bali dan Nekropolis Gilimanuk. Jakarta: Pusat Penelitian Purbakala dan Peninggalan Nasional. 1977b. Sistim-sistim Penguburan pada Akhir Masa Prasejarah di Bali. Disertasi. Jakarta: Universitas Indonesia. Tidak dipublikasikan. 
1979 "The significance of excavation at Gilimanuk (Bali)" dalam R.B. Smith \& W. Watson (eds.) Early South East Asia. New York: Oxford University Press. HIm. 185-198.

1995. "A late prehistoric burial system in Indonesia: additional notes on Gilimanuk, Bali”. Conference Papers on Archaeology in South East Asia. Hongkong: The University Museum and Art Gallery the University of Hongkong. Hlm.181-189.

Souiden, Y., K. Chaieb, O. Chehab \& K. Mahdouani. 2009. "Allele frequencies of ten short tandem repeats loci in the Central Tunisian human population" dalam Journal of Genetics 88. HIm. 119-122.

Sukadana, A.A. 1970. "Persamaan mutilasi dentisi pada kerangka2 prasedjarah dari Liang Bua, Lewoleba, dan Melolo, serta beberapa tjatatan anthropologis mengenai penemuan2 itu" dalam Madjalah Kedokteran Gigi Surabaja 3. HIm. 13-30.

1975. "Tengkorak-tengkorak purba dari P. Komodo". Kumpulan Naskah Pertemuan Nasional Ahli Anatomi Indonesia III. Denpasar: Perhimpunan Ahli Anatomi Indonesia.

1979. "Perubahan-perubahan pada tulang dan gigi subfosil manusia dan aplikasinya dalam penentuan kronologi peninggalan itu" dalam Berkala IImu Kedokteran 11. HIm. 57-68.

1981. "Peninggalan manusia di Liang Bua dan hubungannya dengan penemuan di Lewoleba dan Melolo" dalam Berkala Bioanthropologi Indonesia 1. HIm. 53-72.

1983. "Metodologi sampling populasi berhubung dengan kekhususan konstelasi dan sejarah antropologik Indonesia" dalam Berkala Bioantropologi Indonesia 4. HIm. 17-27.

1984. Studi Politipisme dan Polimorfisme Populasi pada Beberapa Peninggalan di Nusa Tenggara Timur. Disertasi. Surabaya: Universitas Airlangga. Tidak dipublikasikan.

Sun, G., S.T. McGarvey, R. Bayoumi, C.J. Mulligan, R. Barrantes, S. Raskin, Y. Zhong, J. Akey, R. Chakraborty \& R. Deka. 2003. "Global genetic variation at nine short tandem repeat loci and implications on forensic genetics" dalam European Journal of Human Genetics 11. HIm. 39-49.

Suprijo, A. 1982. "Penelitian terhadap rangka Gilimanuk tahun 1977". Rapat Evaluasi Hasil Penelitian Arkeologi I. Jakarta: Pusat Penelitian Arkeologi Nasional.

1985. "Penelitian terhadap rangka Gilimanuk tahun 1979". Rapat Evaluasi Hasil Penelitian Arkeologi II. Jakarta: Pusat Penelitian Arkeologi Nasional.

1991. "Karies gigi pada rangka Gilimanuk". Proceedings Analisis Hasil Peneltian Arkeologi II: Kehidupan Ekonomi Masa Lampau Berdasarkan Data Arkeologi Jilid I. Jakarta: Departemen Pendidikan dan Kebudayaan.

Suriyanto, R.A. 2007. "Perbedaan karakteristik-karakteristik epigenetis upper viscerocranium dari sampel tengkorak Liang Bua, Lewoleba, Melolo, dan Ntodo Leseh (Nusa Tenggara Timur) dan Gilimanuk (Bali)" dalam Berkala Arkeologi Vol. 27 No. 1. HIm. 72-106. 
2012. "Maskulinisasi dimorfisme seksual dalam karakteristik-karakteristik epigenetik neurokranium Gilimanuk" dalam Masyarakat Kebudayaan dan Politik 1. HIm. 15-33.

Suriyanto, R.A., T. Jacob, S. Aswin \& E. Indriati. 2006. "Kajian perbandingan karakteristik epigenetis populasi tengkorak manusia Paleometalik Gilimanuk (Bali) dan Liang Bua, Lewoleba, Melolo dan Ntodo Leseh (Nusa Tenggara Timur)" dalam Humanika 19. HIm. 43-64.

Suriyanto, R.A., J. Hastuti, N.T. Rahmawati, Koeshardjono \& T. Jacob. 2008. "Acromiocristalis populasi pygmy Rampasasa (Kabupaten Manggarai, Pulau Flores, Propinsi Nusa Tengara Timur)" dalam Masyarakat Kebudayaan dan Politik 3. HIm. 272-282.

Suriyanto, R.A. \& T. Koesbardiati. 2006. "Karakteristik-karakteristik epigenetis dan metris upper viscerocranium manusia prasejarah Liang Bua, Lewoleba, Melolo dan Ntodo Leseh di Nusa Tenggara Timur" dalam Jurnal Anatomi Indonesia 1. Hlm. 60-70.

2010. "Dental modifications: a perspective of Indonesian chronology and the current applications" dalam Dental Journal 43. HIm. 81-90.

2012. "Australomelanesoid and Mongoloid population in Indonesia: a picture of migration and hybridization since prehistoric until present times". International Seminar The Cross Culture and History of Asia Pacific in Indonesia, organized by Forum for the Asia Pacific Culture and History Studies (For APACHIS), Danau Toba International Hotel, July 11 - 12 , 2012.

Suriyanto, R.A., T. Koesbardiati, \& D.B. Murti. 2011. "The dental modifications in ancient until present Indonesia: a chronological evidence of Indonesian racial identity" dalam Papua 2. HIm. 1-41.

Suriyanto, R.A., T. Koesbardiati, D.B. Murti \& E. Indriati. 2012. "Mongoloidization around Neolithic until present Indonesia: a perspective of dental modifications". Proceeding Book the $2^{\text {nd }}$ International Joint Symposium on Oral and Dental Sciences. Yogyakarta: The Indonesian Journal of Dental Research Faculty of Dentistry Universitas Gadjah Mada. HIm. 213-224.

Underhill, P.A., G. Passarino, A.A. Lin, S. Marzuki, P.J. Oefner, L.L. Cavalli-Sforza \& G.K. Chambers. 2001. "Maori origins, Y-chromosome haplotypes and implications for human history in the Pacific" dalam Human Mutation 17. HIm. 271-280.

Vecchio, G., L. Garofano, L. Saravo, S. Spitaleri, G. lacovacci, M. Santacroce, V. Manzari \& B. Budowle. 2004. "Allele frequencies for CODIS loci in a Sicilian population sample" dalam International Congress Series 1261. HIm. 136-138.

Wikarman, I.N.S. 1994. Leluhur Orang Bali. Bangli: Yayasan Widya Shanti.

Witas, H.W. 2001. "Molecular anthropology: Touching the past through ancient DNA retrieval, methodological aspects" dalam Anthropological Review 64. HIm. 41-56.

Xu, S., I. Pugach, M. Stoneking, M. Kayser, Y. Jin \& the HUGO Pan-Asian SNP Consortium. 2012. "Genetic dating indicates that the Asian-Papuan admixture through eastern Indonesia corresponds to the Austronesian expansion" dalam Proceeding of the National Academy of Sciences USA 109. HIm. 4574-4579. 
Yang, Y. \& K. Watt. 2005. "Contamination controls when preparing archaeological remains for ancient DNA analysis" dalam Journal of Archaeological Science 32. HIm. 331-336.

Yuliati, C. 1995. Laporan Ekskavasi Situs Gilimanuk Kecamatan Melaya Kabupaten Jembrana Propinsi Bali. Denpasar: Balai Arkeologi Denpasar. Tidak dipublikasikan.

1997. Laporan Penelitian Arkeologi, Ekskavasi Situs Gilimanuk Kecamatan Melaya Kabupaten Jembrana. Denpasar: Balai Arkeologi Denpasar. Tidak dipublikasikan. 
